\title{
Pharmacognosy
}

\section{Formulation development and evaluation of Silybum marianum tablets}

\author{
Valeria Andrea Cianchino ${ }^{1}$, Laura Silvina Favier ${ }^{1,3.4}$, Claudia Alicia Ortega ${ }^{1}$, Cecilia Peralta ${ }^{1}$ \\ \& Diego Alberto Cifuente ${ }^{2}$
}

\begin{abstract}
In popular medicine Silybum marianum is used as a hepatoprotective agent. Silymarin is the major constituent. The present work deals with the formulation and evaluation of S. marianum tablets from ethanolic extract by direct compression. The ethanolic extract was obtained from seeds by soxhlet extraction. Two pharmaceutical formulations were prepared using fluid extract as an active principle, and Aeroperl ${ }^{\circledR} 300$ Pharma as a carrier. In order to improve flow ability and compressibility, co-processed excipients MicroceLac ${ }^{\circledR} 100$ and FlowLac ${ }^{\circledR} 90$ were employed. Pre-compression and post-compression parameters were evaluated according to USP 34-NF 29. Besides, silymarin was determined by NMR spectral data. Both formulations showed excellent rheological properties and the best biopharmaceutical parameters were observed in F2 (S. marianum ethanolic extract, aeroperl $^{\circledR} 300$ Pharma, flowLac ${ }^{\circledR} 90$, glycolate starch and magnesium stearate) in terms of the friability $(0.82$ $\%)$ and the disintegration time $(8.05 \mathrm{~min})$.
\end{abstract}

Key words: direct compression, ethanolic extract, herbal tablets, quality controls, Silybum marianum.

\section{Resumen}

En medicina popular, Silybum marianum se usa como agente hepatoprotector. La silimarina es su componente principal. El presente trabajo trata de la formulación y evaluación de tabletas de S. marianum a partir de extracto etanólico por compresión directa. El extracto etanólico se obtuvo de las semillas mediante extracción con soxhlet. Se prepararon dos formulaciones farmacéuticas usando extracto fluido como principio activo y Aeroperl ${ }^{\circledR} 300$ Pharma como vehículo. Para mejorar la capacidad de flujo y la compresibilidad, se emplearon excipientes coprocesados MicroceLac ${ }^{\circledR} 100$ y FlowLac ${ }^{\circledR}$ 90. Los parámetros de precompresión y postcompresión se evaluaron de acuerdo con USP 34-NF 29. Además, la silimarina se determinó mediante datos espectrales de RMN. Ambas formulaciones mostraron excelentes propiedades reológicas y los mejores parámetros biofarmacéuticos se observaron en F2 (S. marianum ethanolic extract, aeroper ${ }^{\mathbb{E}} 300$ Pharma, flowLac ${ }^{\circledR} 90$, glicolado de almidón y estearato de magnesio) en términos de friabilidad $(0,82 \%)$ y el tiempo de desintegración ( $8,05 \mathrm{~min})$.

Palabras clave: compresión directa, extracto etanólico, comprimidos herbarios, controles de calidad, Silybum marianum.

\section{Introduction}

Silybum marianum (L.) Gaertn, "cardo mariano", is employed in popular medicine as a hepatoprotective herbal medicine (Flora et al. 1998; Freitag et al. 2015; Bouhalit \& Kechrid 2018). A set of flavolignans, called silymarin, are the main active ingredients of $S$. marianum extract: silybin A and B (I), isosilybin A and B (I) and silychristin (II) (Fig. 1). Silymarin is poorly soluble in water and it is usually administered in oral forms (Ramírez-Santos et al. 2011; Shakeela et al. 2014).

The proposed dose of silymarin in the tablets is approximately the dose contained in one cup of tea prepared from $2 \mathrm{~g}$ of vegetable drug (Alonso 2004).

\footnotetext{
${ }^{1}$ Universidad Nacional de San Luis, Área de Tecnología Farmacéutica, Ejercito de los Andes 950, San Luis, Argentina.

${ }^{2}$ Universidad Nacional de San Luis, Área de Química Orgánica, INTEQUI-CONICET, Almirante Brown 1500, San Luis, Argentina.

${ }^{3}$ ORCID: <https://orcid.org/0000-0002-3875-3388>

${ }^{4}$ Author for correspondence: laurasi165@gmail.com
} 
<smiles>COc1cc(C2Oc3cc(C4Oc5cc(O)cc(O)c5C(=O)[C@H]4O)ccc3O[C@@H]2[N]O)ccc1O</smiles>

I: silybin A, B, isosilybin A,B

Figure 1 - Major flavolignans present in silymarin.

In the Argentinean market, silymarin is present under the form of tablets obtained by wet granulation (Laragon 150 commercial tablets, Roemmers (CT)); however, $S$. marianum herbal tablets obtained by dry route and direct compression are not available.

In recent years, the use of herbal medicinal products has increased in importance across the world and novel pharmaceutical formulations are required (WHO 2004). Tablets are the most common solid pharmaceutical dosage formulation used by humans and they are conventionally prepared by wet granulation (WG), dry granulation (DG) and direct compression (DC) (Vila Jato 2001). DC produces tablets with faster dissolution times and requires a smaller number of production steps (Remington 2003). Aeroperl ${ }^{\circledR} 300$ Pharma is an excellent pharmaceutical absorbent for direct compression. This hydrophilic fumed silica is used as carrier in solid dosage forms since it allows the incorporation of fluid extracts and at the same time it improves dissolution of poorly soluble active principles (Desai 2016; Wei et al. 2017).

Direct compression formulations consist of four basic ingredients: a diluent to increase the bulk, a lubricant to improve flow of blend, a disintegrant to improve the biodisponibility and the active ingredient (Singh et al. 2004). The excipients have to compensate for poor flow and compression properties, which are often inherent to the active extract (Jivraj et al. 2000; Shubhajit \& Changquan 2018). In this sense, lactose co-processed excipients improve process ability, performing as diluent and disintegrant agents (Villafuerte Robles 2011; Mamatha et al. 2017).

In the present work we report a novel formulation to obtain herbal tablets of S. marianum by direct compression using MicroceLac $100^{\circledR}$ (75\% alpha-lactose monohydrate and $25 \%$ microcrystalline cellulose) and FlowLac $90^{\circledR}$<smiles>COc1cc([C+]2c3cc(C4Oc5cc(O)cc(O)c5C(=O)C4O)ccc3O[C@@]2(C(=O)O)C(F)(F)F)ccc1O</smiles>

II: silychristin

(spray-dried alpha-lactose monohydrate) as lactose co-processed excipients. Also, starch glycolate was used as a superdisintegrant and magnesium stearate as a lubricant.

In addition, the NMR fingerprint of tablets prepared with silymarin was made.

\section{Materials and Methods}

Silymarin, organic solvents, chemicals and reagents of analytical grade were purchased from Sigma-Aldrich. The direct compression excipients investigated in this study included: Aeroperl ${ }^{\circledR}$ 300 Pharma, MicroceLac ${ }^{\circledR} 100$ and FlowLac ${ }^{\circledR} 90$ (Meggle Pharma, Germany) and were donated by Etilfarma. Glycollate starch and magnesium stearate were purchased from Droguería Saporiti S.A.C.I.F.I.A.

The seeds of Silybum marianum were purchased in an herbal shop from the city of San Luis (Argentina) and were identified as genuine by macro and microscopic techniques. The ethanolic extract was obtained by following official methods. The quantitative analysis of silymarin was performed by UV-vis spectrophotometric method (UV-vis Spectrophotometer, Beckman, DU-640) (Gul et al. 2015). Concentration of silymarin was determined as $1.96 \mathrm{mg} / \mathrm{mL}$ from the calibration curve.

Granulate was obtained by immersing the extract in Aeroperl ${ }^{\mathbb{B}}$ used as a carrier, in a 1:1 ratio (Sun et al. 2018). The evaporation of the solvent was carried out under reduced pressure and then dried in an oven $\left(40{ }^{\circ} \mathrm{C}\right)$ to constant weight. Two tablet formulations (F1 and F2) were proposed using different diluents (FlowLac $90^{\circledR}$ and MicroceLac ${ }^{\circledR}$ 100 , respectively) (Tab. 1).

The dynamic for each mixture of powder was determined by the funnel method as described in the literature (Lantz \& Schwartz 1990). To determine the density of the samples, the powder 
Table 1 - Composition of tablets.

\begin{tabular}{lcc}
\hline \multirow{2}{*}{ Components } & \multicolumn{2}{c}{ Formulations } \\
\cline { 2 - 3 } Silybum marianum ethanolic extract (mL/tablet) & F1 & F2 \\
Aeroperl® 300 Pharma (mg/tablet) & 26 & 26 \\
MicroceLac ${ }^{2} 100$ (mg/tablet) & 26 & 26 \\
FlowLac® 90 (mg/tablet) & 74.1 & ---- \\
Glycolate starch (mg/tablet) & ---- & 74.1 \\
Magnesium stearate (mg/tablet) & 2.6 & 2.6 \\
\hline
\end{tabular}

was gently poured into $10 \mathrm{~cm}^{3}$ graduate cylinder to a total volume of $10 \mathrm{~cm}^{3}$. The bulk density (DB) was calculated as the ratio between weight (g) and volume $\left(\mathrm{cm}^{3}\right)$. To determine the final tapped density (DT) the cylinder was tapped with
1 inch vertical drop, at 1 second interval, until no measurable change in volume was noticed. The compressibility of the powder was evaluated using the Hausner Ratio (HR) (Schmidt \& Rubensdörfer 1994) (Tab. 2).

Table 2 - Densities and flow properties of physical mixtures containing Silybum marianum ethanolic extract.

\begin{tabular}{lcc}
\hline Properties & \multicolumn{2}{c}{ Formulations } \\
\hline Bulk density $\left(\mathrm{g} / \mathrm{cm}^{3}\right)$ & F1 & $0.59 \pm 0.001$ \\
Tapped density $\left(\mathrm{g} / \mathrm{cm}^{3}\right)$ & $0.54 \pm 0.003$ & $0.67 \pm 0.013$ \\
Compressibility $(\%)$ & $14.39 \pm 0.54$ & $12.05 \pm 0.005$ \\
Hausner ratio & $1.16 \pm 0.005$ & $1.14 \pm 0.02$ \\
Angle of repose $(\theta)$ & $10.23 \pm 1.2$ & $8.7 \pm 0.45$ \\
\hline
\end{tabular}

The values represent the mean of three determinations \pm standard deviation.

The extract and excipients, except the magnesium stearate, were blended for 10 minutes by tumbling, then the corresponding amount of magnesium stearate was added and blended for five more minutes; and after that, they were compressed by using a mini-press mono-punch eccentric machine, with a punch set of $7.0 \mathrm{~mm}$ in diameter during 4 minutes. The weight of each tablet was $130 \mathrm{mg}$ (Fig. 2). Tablet hardness was measured with a Scout hardness tester. The tablets previously weighted were loaded into a friabilator USP (Electrolab Dual Drum Friability Tester EF-2) and the friability was evaluated in accordance with USP 34-NF 29 (USP 2011). Friability $(\%)=(\mathrm{W} 1-\mathrm{W} 2 / \mathrm{W} 1) \times 100$. $(\mathrm{W} 1=$ weight of tablets before testing and W2 = weight of tablets after testing).

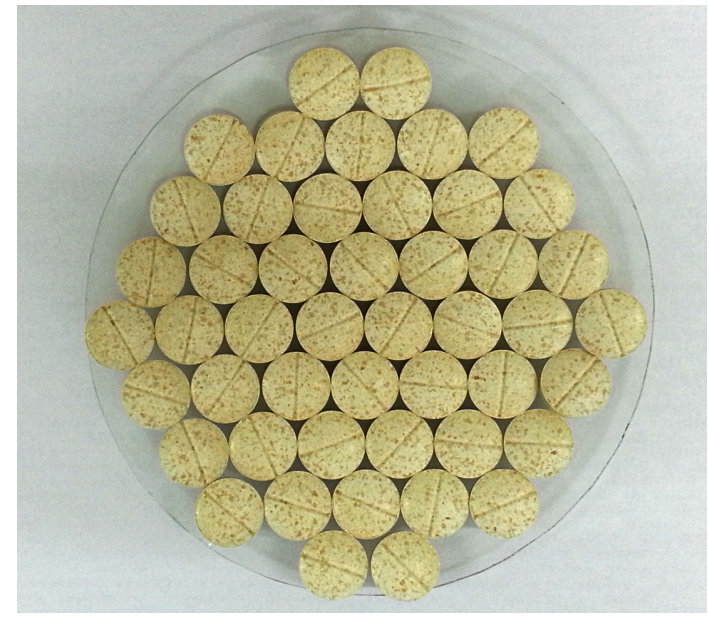

Figure 2 - Prepared tablets from Silybum marianum ethanolic extract. 
The disintegration test was conducted following the method established by the USP (USP 2011). A tablet disintegration test apparatus (Electrolab disintegration tester DT2L) was used to determine the disintegration time for all formulations. Six tablets were placed individually in each tube of the disintegration test apparatus. The phosphate medium was maintained at a temperature of $37 \pm 2{ }^{\circ} \mathrm{C}$ and the time was noted for the entire tablet to complete disintegration.

A USP dissolution test apparatus (Hanson Research SR8PLUS) type II was used for the in vitro dissolution test. First, $900 \mathrm{~mL}$ of the phosphate buffer $\mathrm{pH} 7.5$ with $2 \%$ of sodium lauryl sulfate was placed in a vessel, and the temperature was maintained at $37 \pm 0.5^{\circ} \mathrm{C}$. The speed of the paddle was fixed at $100 \mathrm{rpm}$. Dissolution samples were then withdrawn at 5 minute intervals. Drug concentration was calculated by measuring the absorbance at $287 \mathrm{~nm}$ from the standard calibration curve previously obtained using silymarin (SigmaAldrich) and expressed as a percentage of the cumulative drug dissolved. The test was performed in triplicate (USP 2011).

The quantitative analysis of silymarin in F1, F2 and in Laragon 150 commercial tablets (CT) was performed by spectrophotometry (Meghreji et al. 2010). All determinations were made in triplicate.

Five tablets of F1, F2 and CT were finely powdered. An amount of the powdered tablet equivalent to $50 \mathrm{mg} /$ tablet (F1, F2) and $150 \mathrm{mg} /$ tablet (CT) of silymarin were weighed accurately, and extracted into $3 \times 20 \mathrm{ml}$ portions of chloroform with shaking. The residue was filtered using Whatmann No. 42 filter paper. The filtrate was evaporated to dryness under vacuum and the remaining drug was dissolved in methanol and diluted to $100 \mathrm{~mL}$. The final concentration of silymarin was about $0.5 \mathrm{mg} / \mathrm{mL}(\mathrm{F} 1, \mathrm{~F} 2)$ and 1.5 $\mathrm{mg} / \mathrm{mL}$ (CT). Suitable dilutions were done with methanol before measurements. As a positive control was used CT because it is developed by a leader laboratory.

NMR $\left({ }^{1} \mathrm{H}-,{ }^{13} \mathrm{C}\right.$ - and ${ }^{13} \mathrm{C}{ }^{1} \mathrm{H}$ HSQC) spectral data of F2, CT and silymarin were obtained in a Bruker Spectra AC-200 (200 MHz, $50 \mathrm{MHz})$ in Acetone- $d_{6}$ (Lee \& Liu 2003; Liu \& Lee 2012).

All results were expressed as mean values \pm standard deviation (SD). The dissolution data was subject to statistical analysis using a computer program, Graphpad INSTAT tm Copyright 1990-1993 (2.04 version, Ralf Stahlman, Purdue
University, USA, 931897S) for a one-way analysis of variance (ANOVA). $\mathrm{P}<0.05$ was considered as evidence of a significant difference.

\section{Results and Discussion}

In the present study, the ethanolic extract of Silybum marianum was employed as an active ingredient to design, develop and evaluate tablets by direct compression. The fluid extract was obtained by soxhlet extraction and the concentration of silymarin was determined by UV-visible spectrometry $(1.96 \mathrm{mg} / \mathrm{mL})(\mathrm{Gul}$ et al. 2015).

Two appropriate formulations for direct compression were prepared. Their compositions are shown in Table 1. Both formulations have $S$. marianum extract as active ingredient. Because silymarin has poor solubility, Aeroperl ${ }^{\circledR} 300$ Pharma was used as carrier. The liquid crude extract of the plant was adsorbed by immersing it in granulated colloidal silicon dioxide (Aeroper ${ }^{\circledR}$ 300 Pharma) in 1:1 relation. In addition, two lactose excipients of pharmaceutical degree, frequently used in direct compression, were employed as diluent agents: MicroceLac ${ }^{\circledR} 100$ and FlowLac ${ }^{\circledR} 90$. Both derive from nature and are frequently used as diluent/binder agents in oral dosage. These kinds of co-processed excipients provide a better tableting performance (Lamešićet al. 2017; Mužíková et al. 2018).

On the other hand, pre-compression and postcompression parameters were evaluated according to official standards. Table 2 shows the densities and flow properties of physical mixtures containing S. marianum ethanolic extract. The powders of both formulations flowed very well, given that the corresponding angles of repose between $7^{\circ}$ and $13^{\circ}$ were less than $25^{\circ}$. The experimental values indicated that both powder mixtures possess good flow properties and good packing ability, and at the same time they meet the official requirements (Lantz \& Schwartz 1990).

The tablets were obtained by direct compression using a mono-punch eccentric machine with $7 \mathrm{~mm}$-diameter punches (Fig. 2). The prepared tablets were evaluated for uniformity of weight, hardness, friability and disintegration time. The experimental results obtained are shown in Table 3. Both batches of the manufactured tablets were acceptable according to the US pharmacopeia. The variation in weight was less than $10 \%$ (USP 2011). This parameter confirmed the consistency of dosage units during compression. As soon as to 
Table 3 - Results of control tests performed on Silybum marianum tablet.

\begin{tabular}{lcc}
\hline \multirow{2}{*}{ Properties } & \multicolumn{2}{c}{ Formulations } \\
\cline { 2 - 3 } & F1 & F2 \\
\hline Weight variation (mg) & $129.7 \pm 1.05$ & $134.2 \pm 0.61$ \\
Friability (\%) & $0.92 \pm 0.015$ & $0.82 \pm 0.03$ \\
Disintegration time (min) & $19.4 \pm 0.15$ & $8.05 \pm 0.03$ \\
Hardness $\left(\mathrm{kg} / \mathrm{cm}^{2}\right)$ & $4.40 \pm 0.11$ & $3.70 \pm 0.17$ \\
\hline
\end{tabular}

The values represent the mean of three determinations \pm standard deviation.

friability, both formulations had a loss weighing less than $1 \%$, which would determine a higher resistance to abrasion. In relation to the disintegration time, F2 showed the lowest value that would be related with their lower hardness value. Hardness is an important parameter to estimate the disintegration time, since the resistant tablets do not disintegrate in the time required to satisfy the dissolution specifications (Da Silva Solon et al. 2010).

The content of silymarin in F1, F2 and CT was shown in Table 4. All the formulations were within the limits set by the USP (2011).

Table 4 - Analysis of silymarin in S. marianum tablet formulations (F1, F2) and commercial tablets (CT).

\begin{tabular}{lcc}
\hline Formulation & Silymarin Nominal quantity (mg) & Silymarin Found (mg) \pm SD \\
\hline F1 & 50 & $49.16 \pm 0.0059$ \\
F2 & 50 & $50.47 \pm 0.0067$ \\
CT & 150 & $150.30 \pm 0.0031$ \\
\hline
\end{tabular}

Moreover, the cumulative amount of drug released over time was calculated for both formulations. The in vitro dissolution profiles are shown in Figure 3. At 45 minutes Q (\%) the experimental values were: $96.430 \pm 0.101(\mathrm{CT})$, $86.589 \pm 0.003(\mathrm{~F} 2)$ and $67.533 \pm 0.088(\mathrm{~F} 1)$.

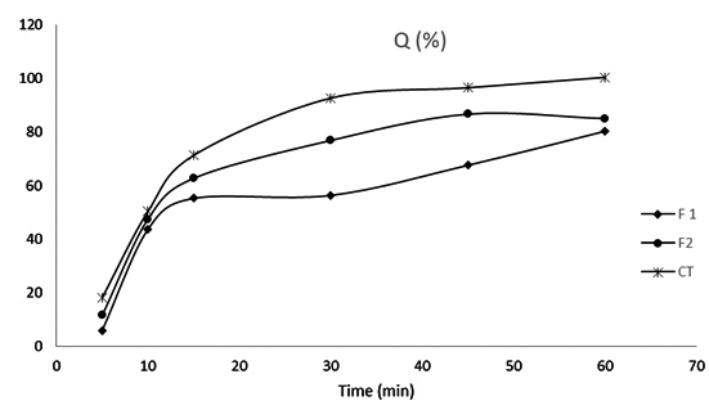

Figure 3 - In vitro dissolution profiles test of $S$. marianum tablet formulations $(\mathrm{F} 1, \mathrm{~F} 2)$ and commercial tablets (CT). profiles test.
The dissolution test for tablets described in the USP indicates that no less than $75 \%$ of silymarin content should be dissolved in 45 minutes. Consequently, F2 and CT satisfied this official specification, evidencing their excellent galenic and pharmacokinetic features. Additionally, F2 presented parameters of in vitro release closer to CT. These results could be attributed to the absence of microcrystalline cellulose in F2.

Furthermore, mono and bi-dimensional NMR techniques were used to identify silymarin in the manufactured tablets (F2). These data were identified and compared with silymarin from CT and with silymarin Sigma-Aldrich (Kim et al. 2003; Bijak 2017). ${ }^{1} \mathrm{H}-\mathrm{NMR}$ fingerprint is a useful secondary quality assurance method for the standardization of silymarin. In the ${ }^{1} \mathrm{H}-\mathrm{NMR}$ spectrum of $\mathrm{F} 2$, in accordance with the information provided by the literature and compared with CT and with silymarin Sigma-Aldrich, the presence of the major constituents was divided into eight 


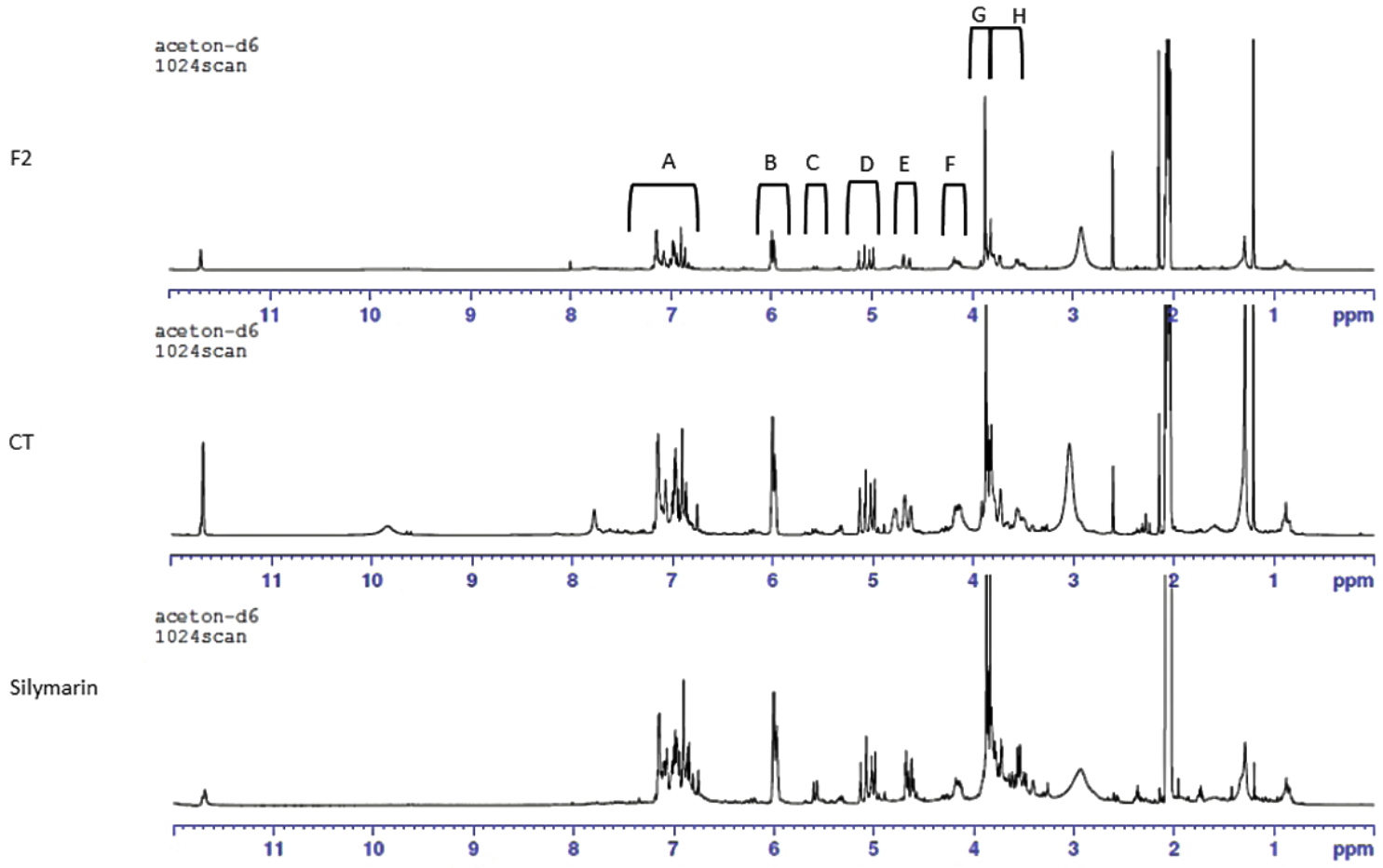

Figure $4-{ }^{1}$ H NMR spectrum of $S$. marianum tablet formulation (F2), commercial tablets (CT) and silymarin).

areas (A-H) (Fig. 4). Each area clearly represented the structural features of flavolignans informed in the literature. The assignment of areas A-H is summarized in Table 5. Among these eight areas, area $\mathrm{C}$ represents the unique signal of $\mathrm{H}-7$ "of silychristin (II) at $5.61 \mathrm{ppm}(d, \mathrm{~J}=7 \mathrm{~Hz})$. Area $\mathrm{F}$ only contributed to H-8" of silybin A and B (I), isosilybin $\mathrm{A}$ and $\mathrm{B}$ (I) at $4.15 \mathrm{ppm}$ as multiplet.

From $2 \mathrm{D}{ }^{13} \mathrm{C}^{1} \mathrm{H}-\mathrm{HSQC}$ twelve regions were determined in the ${ }^{13} \mathrm{C}$-NMR fingerprint of silymarin of prepared tablets, compared with $\mathrm{CT}$ and silymarin Sigma-Aldrich (Fig. 5). The assignment

Table 5 - ${ }^{1} \mathrm{H}-\mathrm{NMR}$ fingerprint of silymarin.

\begin{tabular}{|c|c|c|}
\hline Areas & Protons & Assignment \\
\hline $\mathrm{A}(\delta 6.80 \sim 7.20)$ & H-2', H-5', H-6' & Silybin A and B (I), Isosilybin A and B (I), Silychristin (II). \\
\hline $\mathrm{B}(\delta 5.93 \sim 6.05)$ & H-6, H-8 & Silybin A and B (I), Isosilybin A and B (I), Silychristin (II). \\
\hline $\mathrm{C}(\delta 5.56 \sim 5.60)$ & $\mathrm{H}-7 ”$ & Silychristin (II). \\
\hline \multirow[t]{2}{*}{$\mathrm{D}(\delta 4.95 \sim 5.15)$} & $\mathrm{H}-2$ & Silybin A and B (I), Isosilybin A and B (I), Silychristin (II). \\
\hline & $\mathrm{H}-7 ”$ & Silybin A and B (I), Isosilybin A and B (I). \\
\hline $\mathrm{E}(\delta 4.60 \sim 4.70)$ & $\mathrm{H}-3$ & Silybin A and B (I), Isosilybin A and B (I), Silychristin (II). \\
\hline $\mathrm{F}(\delta 4.10 \sim 4.25)$ & $\mathrm{H}-8 ”$ & Silybin A and B (I), Isosilybin A and B (I). \\
\hline$C(8,272,200)$ & $\mathrm{OCH}_{3}$ & Silybin A and B (I), Isosilybin A and B (I), Silychristin (II). \\
\hline$G(d 3.72 \sim 3.90)$ & H-9” & Silybin A and B (I), Isosilybin A and B (I), Silychristin (II). \\
\hline \multirow[t]{2}{*}{$\mathrm{H}(\delta 3.40 \sim 3.70)$} & $\mathrm{H}-8 ”$ & Silychristin (II). \\
\hline & H-9” & Silybin A and B (I), Isosilybin A and B (I), Silychristin (II). \\
\hline
\end{tabular}




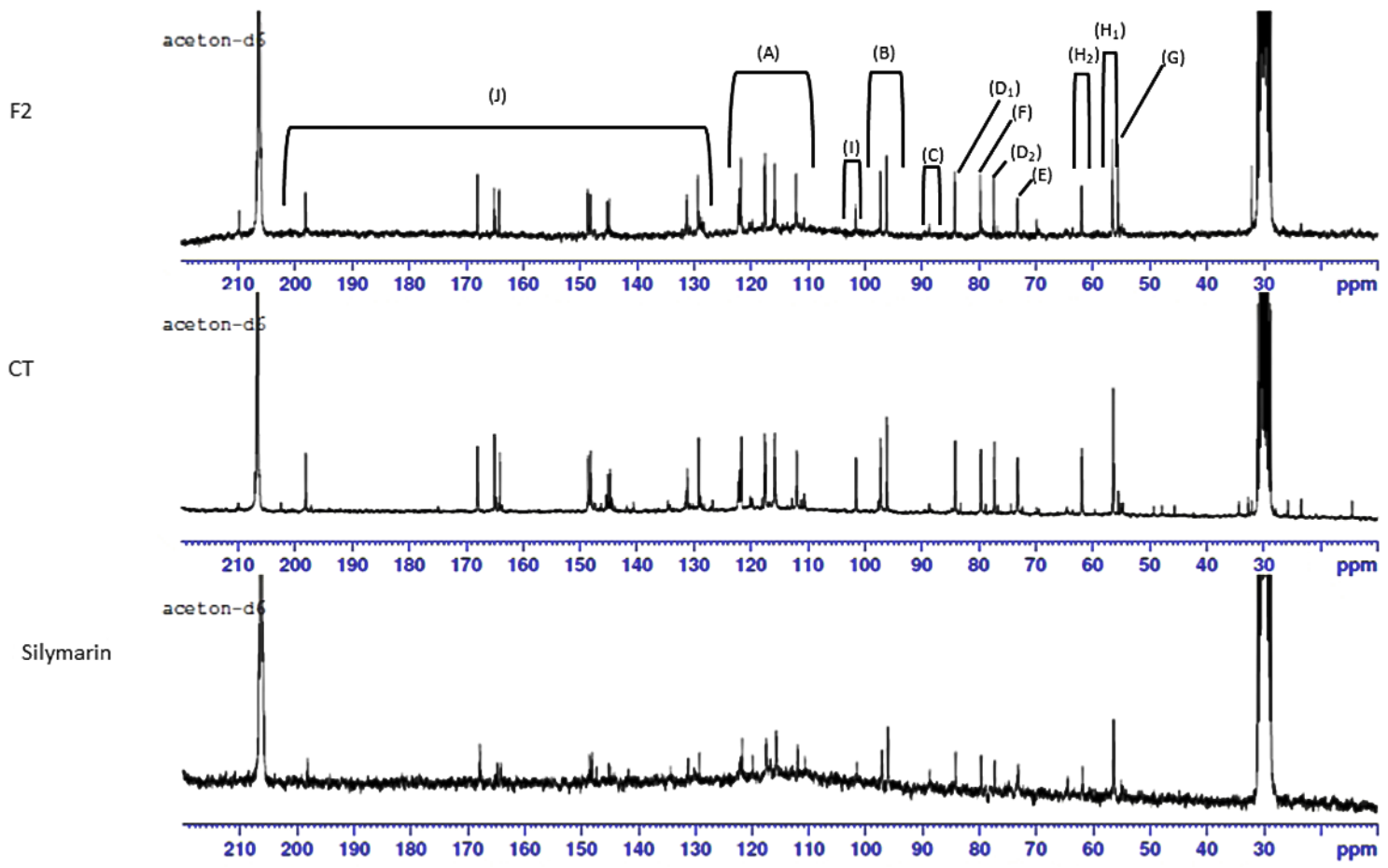

Figure $5-{ }^{13} \mathrm{C}$ NMR spectrum of $S$. marianum tablet formulation (F2), commercial tablets (CT) and silymarin.

of areas A-J is shown in Table 6. Among these areas, four were characteristic areas: area C (C-7", $\left.d_{C} 88.67, \mathrm{~d}\right)$ of silychristin (II); area $\mathrm{D}_{2}\left(\mathrm{C}^{-} 7^{\prime}, d_{C}\right.$ $77.35, \mathrm{~d})$ of silybin A and B (I), isosilybin A and
$\mathrm{B}(\mathrm{I})$; area $\mathrm{F}\left(\mathrm{C}-8\right.$ ", $\left.d_{C} 79.73, \mathrm{~d}\right)$ of silybin $\mathrm{A}$ and $\mathrm{B}$ (I), isosilybin A and B (I) and area $\mathrm{H}_{1}(\mathrm{C}-8$ ", $d_{C} 56.48, \mathrm{~d}$ ) of silychristin (II). ${ }^{13} \mathrm{C}$-NMR fingerprint takes advantage of the fact that samples contain

Table $6-{ }^{13} \mathrm{C}$-NMR fingerprint of silymarin.

\begin{tabular}{|c|c|c|}
\hline Areas & Carbons & Assignment \\
\hline $\mathrm{A}(\delta 114.05 \sim 122.03)$ & C-2', C-5', C-6' & Silybin A and B (I), Isosilybin A and B (I), Silychristin (II). \\
\hline $\mathrm{B}(\delta 96.17 \sim 97.24)$ & C-6, C-8. & Silybin A and B (I), Isosilybin A and B (I), Silychristin (II). \\
\hline $\mathrm{C}(\delta 88.67)$ & C-7" & Silychristin (II). \\
\hline $\mathrm{D}_{1}(\delta 84.20)$ & $\mathrm{C}-2$ & Silybin A and B (I), Isosilybin A and B (I), Silychristin (II). \\
\hline $\mathrm{D}_{2}(\delta 77.35)$ & C-7" & Silybin A and B (I), Isosilybin A and B (I). \\
\hline $\mathrm{E}(\delta 73.25)$ & $\mathrm{C}-3$ & Silybin A and B (I), Isosilybin A and B (I), Silychristin (II). \\
\hline $\mathrm{F}(\delta 79.73)$ & C-8" & Silybin A and B (I), Isosilybin A and B (I). \\
\hline $\mathrm{G}(\delta 55.58)$ & $\mathrm{OCH} 3$ & Silybin A and B (I), Isosilybin A and B (I), Silychristin II). \\
\hline $\mathrm{H}_{1}(\delta 56.48)$ & C-8” & Silychristin (II). \\
\hline $\mathrm{H}_{2}(\delta 61.95)$ & C-9" & Silybin A and B (I), Isosilybin A and B (I), Silychristin (II). \\
\hline $\mathrm{I}(\delta 101.62)$ & $\mathrm{C}-10$ & Silybin A and B (I), Isosilybin A and B (I), Silychristin (II). \\
\hline $\mathrm{J}(\delta$ 129.31 198.19) & $\begin{array}{l}\text { C-9, C-5, C-7, C-4, C-1', } \\
\text { C-3', C-4', C-1", C-3", C-4"' }\end{array}$ & Silybin A and B (I), Isosilybin A and B (I), Silychristin (II). \\
\hline
\end{tabular}


simplified profiles with minimal signal overlap (Sharmin \& Zafar 2017).

In conclusion, the formulation prepared in this study F2 showed excellent technology and quality parameters. This formulation could be used for herbal tablets of fluid extracts with poorly soluble actives, such as silymarin, ensuring their stability by avoiding heat and humidity factors during the manufacturing process.

\section{Acknowledgements}

We would like to thank the Universidad Nacional de San Luis (PROICO 02-1718) and Consejo Nacional de Investigaciones Científicas y Técnicas CONICET for supporting our study, and Ms Cs. Leandro Berroa Gómez from Etilfarma for the excipients he provided to us.

\section{References}

Alonso J (2004) Tratado de fitofármacos y nutracéuticos. $1^{\mathrm{a}}$ ed. Corpus, Santa Fe. 280p.

Bijak M (2017) Silybin, a major bioactive component of milk thistle (Silybum marianum L. Gaernt.)Chemistry, bioavailability, and metabolism. Molecules 22: 1-11.

Bouhalit S \& Kechrid Z (2018) Protective effect of silymarin extracted from Silybum marianum seeds upon nickel-induced hepatotoxicity in albino Wistar Rats. Annals of Microbiology and Immunology 1: $1-5$.

Da Silva Solon LG, de Oliveira AIM, Coelho G, Guerra B, Alberto L, Soares L \& Antunes de Araújo A (2010) Determination of carbamazepine in pharmaceutical formulations. Brazilian Journal of Pharmaceutical Sciences 46: 509-513.

Desai P, Liew C \& Heng P (2016) Review of disintegrants and the disintegration phenomena. Journal of Pharmaceutical Sciences 105: 2545-2555.

Freitag AF, Esteves Cardia GF, Da Rocha BA, Aguiar RP, Silva-Comar FM, Spironello RA, Grespan R, Caparroz-Assef SM, Bersani-Amado CA \& Cuman RK (2015) Hepatoprotective effect of silymarin (Silybum marianum) on hepatotoxicity induced by acetaminophen in spontaneously hypertensive rats. Evidence-Based Complementary and Alternative Medicine 2015: 1-8.

Flora K, Hahn M, Rosen H \& Benner K (1998) Milk thistle (Silybum marianum) for the therapy of liver disease. American Journal of Gastroenterology 93: 139-143.

Gul S, Khanum K \& Mujtaba N (2015) New validated method for analysis of silymarin in polyherbal formulation (aqueous extract, oral liquid and solid dosage form). Chemistry International 1: 103-106.

Jivraj M, Martini G \& Thomson M (2000) An overview of the different excipients useful for the direct compression of tablets. Pharmaceutical Science \& Technology Today 3: 58-63.

Kim NC, Graf TN, Sparacino CM, Wani MC \& Wall ME (2003) Complete isolation and characterization of silybins and isosilybins from milk thistle (Silybum marianum). Organic \& Biomolecular Chemistry 1: 1684-1689.

Lamešić D, Planinšek O, Lavrič Z \& Ilić I (2017) Spherical agglomerates of lactose with enhanced mechanical properties. International Journal of Pharmaceutics 516: 247-257.

Lantz R \& Schwartz JB (1990) Mixing. In: Lieberman HA, Lachman L \& Schwartz JB (eds.) Pharmaceutical dosage form: tablets. Vol. 2. Marcel Dekker, New York. 38p.

Lee DYW \& Liu Y (2003) Molecular structure and stereochemistry of Silybin A, Silybin B, Isosilybin A, and Isosilybin B, isolated from Silybum marianum (Milk Thistle). Journal of Natural of Products 66: 1171-1174.

Liu YZ \& Lee DYW (2012) Standardization and identification of minor components of Silymarin (MK-001). Chinese Herbal Medicines 4: 237-244.

Mamatha B, Srilatha D, Sivanarayani CH, Kumar Desu P \& Venkateswara Rao P (2017) Co-processed excipients: an overview. World Journal of Pharmaceutical Research 6: 224-237.

Meghreji M, Patel C, Dave J, Badmanaban R \& Patel J (2010) Validated method for Silymarin by spectrophotometry in bulk drug and pharmaceutical formulations. Journal of Chemical and Pharmaceutical Research 2: 396-400.

Mužíková J, Komersová A, Lochař V, Vildová L, Vošoustová B \& Bartoš M (2018) Comparative evaluation of the use of dry binders in a physical mixture or as a coprocessed dry binder in matrix tablets with extended drug release. Acta Pharmaceutica 68: 295-311.

Ramírez-Santos A, Pérez-Bustillo A, González-Sixto B, Suárez-Amor O \& Rodríguez-Prieto MA (2011) Pustulosis exantemática generalizada aguda debida a una infusión de cardo mariano (Silybum marianum). Actas Dermo-Sifiliográficas 102: 744-745.

Remington J (2003) Remington farmacia. Tomo 1, 20 ed. Alfonso R. Gennaro, Ed. Medica Panamericana, Buenos Aires. Pp. 998.

Schmidt PC \& Rubensdörfer CJWP (1994) Evaluation of Ludipress as a 'Multipurpose Excipient' for direct compression. Part I: powder characteristics and tableting properties Journal. Drug Development and Industrial Pharmacy 20: 2899-2925.

Shakeela F, Anwerb K, Shazlya G \& Jamilb S (2014) Measurement and correlation of solubility of bioactive compound silymarin in five different green solvents at $298.15 \mathrm{~K}$ to $333.15 \mathrm{~K}$. Journal of Molecular Liquids 195: 255-258.

Sharmin E \& Zafar F (2017) Spectroscopic analysesdevelopments and applications. Chapter 5: $1 \mathrm{H}$ 
and 13C NMR for the profiling of natural product extracts: theory and applications. Intechopen, London. 81p.

Shubhajit P \& Changquan Calvin S (2018) Systematic evaluation of common lubricants for optimal use in tablet formulation. European Journal of Pharmaceutical Sciences 117: 118-127.

Singh PK, Shuaib M, Iqubal A \& Singh M (2014) Recent advances in direct compression technique for pharmaceutical tablet formulation. International Journal of Pharmaceutical Research and Development 6: 49 -57.

Sun W, Aburub A \& Sun C (2018) A mesoporous silica based platform to enable tablet formulations of low dose drugs by direct compression. International Journal of Pharmaceutics 539: 184-189.

USP - United State Pharmacopoeia (2011) The National Formulary (USP 34-NF 29). The official compendium of standards. Asian edition. United States Pharmacopoeial Convention, Rockville. $1208 p$.

Vila Jato JL (2001) Tecnología Farmacéutica. Vol. II. Formas farmacéuticas. Ed. Síntesis, Madrid. 105p.

Villafuerte Robles L (2011) The excipients and their functionality in pharmaceutical solid products. Revista mexicana de Ciencias Farmacéuticas 42: 18-36.

Wei Q, Keck CM \& Müller RH (2017) Oral hesperidinamorphization and improved dissolution properties by controlled loading into porous silica. International Journal of Pharmaceutics 518: 253-263.

World Health Organization (2004) WHO guidelines on safety monitoring of herbal medicines in pharmacovigilance systems. World Health Organization, Geneva. Pp/ 1-5. 